\title{
PERAN KECAMATAN SEBAGAI PERANGKAT DAERAH DALAM PELAYANAN PERTANAHAN (Studi pada Kecamatan Tanjung Karang Timur)
}

\author{
Upik Hamidah
}

Dosen Bagian Hukum Administrasi Negara FH Universitas Lampung

\begin{abstract}
Abstrak
Kecamatan yang dipimpin camat berdasarkan PP. 38 tahun 2007 dan PP. 41 tahun 2007 merupakan perangkat daerah kabupaten/kota, karenanya perlu diketahui peran kecamatan dalam pelayanan pertanahan setelah adanya pelimpahan berdasarkan norma tersebut dan faktor penghambat peran camat dalam pelayanan pertanahan. Penelitian ini merupakan penelitian yuridis empiris, data sekunder dan primer dikumpulkan melalui wawancara dan studi dokumentasi untuk diolah dan dianalisis secara kualitatif. Hasil penelitian menunjukan bahwa walaupun terdapat pelimpahan kewenangan urusan pertanahan kepada Pemerintah Daerah, dari Walikota kepada camat melalui Peraturan Wali Kota Bandar Lampung namun tidak berpengaruh terhadap peran kecamatan dalam pelayanan pertanahan, karena pelimpahan kewenangan dalam urusan pertanahan kepada Pemda hanya merupakan pelayanan tekhnis pertanahan. Peran kecamatan dalam pelayanan pertanahan karena tugas umum pemerintahan di Kecamatan Tanjungkarang Timur sudah dilaksanakan secara optimal sesuai peraturan perundang undangan yang berlaku, walaupun terdapat beberapa faktor penghambat. Tetapi peran camat dalam pelayanan pertanahan sebagai pengawas, monitoring dan inventarisasi tanah negara melalui pelimpahan wewenang dari walikota belum terlaksana sebagaimana mestinya karena belum ada juklak dan juknis.
\end{abstract}

Kata kunci : Peran Kecamatan, Pelayanan Pertanahan

\section{PENDAHULUAN}

Penyelenggaraan otonomi daerah diharapkan untuk tercapainya kesejahteraan masyarakat, tumbuhnya daya saing daerah dan peningkatan kualitas pelayanan kepada masyarakat. Salah satu kewenangan wajib pemerintah daerah dalam pelayanan kepada masyarakat adalah pelayanan di bidang pertanahan, seperti ditentukan didalam Pasal 13 dan 14 ayat (1) huruf K Undang Undang nomor 32 tahun 2004 tentang Pemerintahan Daerah. Pemerintah daerah adalah gubernur, bupati atau walikota dan perangkat daerah sebagai unsure penyelenggara pemerintahan daerah. kemudian kewenangan Pemerintah Daerah dalam bidang pertanahan dipertegas didalam lampiran Peraturan Pemerintah nomor 38 tahun 2007 tentang Pembagian Urusan Pemerintahan Antara Pemerintah, Pemerintah Daerah Provinsi dan Pemerintahan daerah Kabupaten/Kota.

Berdasarkan Pasal 1 ayat (8) Peraturan Pemerintah No. 41 Tahun 2007 tentang Organisasi Perangkat Daerah, perangkat daerah 
kabupaten/kota adalah unsur pembantu kepala daerah dalam penyelenggaraan pemerintahan daerah terdiri dari :

1. Sekretariat Daerah

2. Sekretariat DPRD

3. Dinas Daerah

4. Lembaga Teknis Daerah

5. Kecamatan

6. Kelurahan

Kecamatan sebagai perangkat daerah kabupaten/kota dipimpin oleh camat mempunyai tugas melaksanakan kewenangan pemerintahan yang dilimpahkan oleh bupati/walikota untuk menangani sebagian urusan otonomi daerah. Oleh karena itu camat berkedudukan dibawah dan bertanggungjawab kepada bupati/walikota melalui Sekretaris Daerah.Pelimpahan sebagian kewenangan oleh bupati/walikota kepada camat dalam melaksanakan kewenangan pemerintahan untuk menangani sebagian urusan otonomi daerah tersebut, ditetapkan dengan peraturan bupati/walikota.

Sehubungan dengan adanya pelimpahan kewenangan dalam pelayanan pertanahan kepada Pemerintah Daerah kabupaten/kota dan kecamatan dan kelurahan merupakan perangkat daerah kabupaten/kota yang paling dekat dengan masyarakat, maka peran kecamatan dalam pelayanan pertanahan akan semakin bertambah, karena dengan adanya pelimpahan sebagian kewenangan kepada kecamatan diharapkan akan berdampak kepada kepatuhan masyarakat dalam melaksanakan hak dan kewajiban sesuai dengan peraturan perundang undangan yang berlaku sehingga akan menjadikan pemerintahan menjadi lebih baik.
Salah satu perangkat daerah Pemerintah Daerah Kota Bandar lampung adalah Kecamatan Tanjungkarang Timur yang merupakan wilayah yang lebih luas dibandingkan dengan kecamatan lain yaitu dengan luas $2.131 \mathrm{Ha}$, terdiri dari 11 (sebelas) kelurahan yang terbagi atas 24 (dua puluh empat) lingkungan dan 269 (dua ratus enam puluh sembilan) Rukun Tetangga. 11 kelurahan yang ada, yaitu Campang Raya, Rawa Laut, Kota Baru, Tanjung Agung, Kebun Jeruk, Sawah Lama, Sawah Brebes, Kedamaian, Tanjung Raya, Tanjung Gading dan Jagabaya I. Kecamatan Tanjung Karang Timur berdasarkan Peraturan Daerah Nomor 4 tahun 2004 tentang Rencana Tata Ruang Wilayah (RTRW) Kota Bandar Lampung tahun 2005-2015 termasuk Bagian Wilayah Kota (BWK) D yang fungsi utamanya sebagai perdagangan/jasa dan kawasan industri, sedangkan fungsi pendukungnya sebagai perumahan, industri kecil dan cagar budaya. Dengan adanya fungsi sebagai perdagangan/jasa dan kawasan industri dan pengembangan perumahan, mengakibatkan Kecamatan Tanjungkarang Timur perkembangan wilayahnya semakin pesat, banyak terjadi peristiwa hukum pertanahan sehingga berdampak meningkat pula pelayanan pertanahan oleh kecamatan. Sedangkan masih banyak tanah yang belum bersertifikat dan juga masih ada masyarakat menguasai tanah yang berstatus tanah negara. Kondisi demikian diharapkan kecamatan dapat berperan secara optimal dalam memberikan pelayanan publik di bidang pertanahan.

Berdasarkan uraian latar belakang diatas, maka permasalahan 
adalah bagaimanakah peran kecamatan sebagai perangkat daerah dalam pelayanan pertanahan di Kecamatan Tanjung Karang Timur Kota Bandar Lampung dan bagaimanakah faktor penghambat peran kecamatan dalam pelayanan pertanahan di Kecamatan Tanjung Karang Timur Kota Bandar Lampung. Ruang lingkup penelitian mengenai pelaksanaan pelayanan pertanahan oleh kecamatan sebagai perangkat daerah, baik berdasarkan tugas umum pemerintahan maupun berdasarkan pelimpahan wewenang dari walikota. serta hambatanhambatan yang dihadapi kecamatan dalam pelayanan pertanahan di Kecamatan Tanjungkarang Timur Kota Bandar Lampung

\section{METODE PENELITIAN}

Pendekatan masalah melalui pendekatan normatif yuridis dan empiris. Data yang digunakan adalah data primer dan data sekunder. Data primer diperoleh dari camat dan pamong setempat yang mendukung perannya serta masyarakat yang memohon pelayanan pertanahan. Data sekunder dari buku literatur hukum dan peraturan perundang undangan.Pengumpulan Data dengan cara studi lapangan yaitu mencari data secara langsung ke informan dengan melakukan wawancara terbuka.dan studi pustaka dilakukan dengan cara membaca, menelaah, mencatat dan mengutip sumber data sekunder. Pengolahan data dilakukan dengan seleksi data, pemeriksaan data, klasifikasi data dan penyusunan data. Setelah data dikumpulkan dan diolah kemudian dianalisis secara deskriptif kualitatif yaitu dengan cara menguraikan hasil penelitian dalam bentuk kalimat secara terperinci dan sistematis kemudian dilakukan interpretasi data yaitu mengartikan kata yang tersusun tersebut, sehingga pembahasan ini akan menuju kesimpulan sebagai jawaban dari permasalahan yang diajukan.

\section{PEMBAHASAN}

\subsection{Pengaturan Kewenangan Dalam Pelayanan Pertanahan}

UU Nomor 22 tahun 1999 yang telah diganti dengan UU Nomor 32 tahun 2004 Tentang Pemerintahan daerah Pasal 13 dan 14 menegaskan bahwa salah satu urusan wajib yang menjadi kewenangan pemerintah daerah propinsi dan pemerintah kabupaten/kota adalah pelayanan pertanahan.

Kemudian PP Nomor 38 Tahun 2007 tentang Pembagian Urusan Pemerintahan Antara Pemerintah, Pemerintah Propinsi, dan Pemerintah Daerah Kabupaten/kota, pada lampirannya menentukan secara rinci kewenangan pemerintah kabupaten/kota dalam mengurus bidang pertanahan meliputi 9 sub bidang yaitu :

1. Bidang ijin lokasi

2. Bidang pengadaan tanah kepentingan umum

3. Bidang Penyelesaian sengketa tanah garapan

4. Bidang penyelesaian masalah ganti kerugian dan santunan tanah untuk pembangunan

5. Bidang penetapan Subyek dan obyek redistribusi tanah serta ganti kerugian tanah kelebihan maksimum dan tanah absentee

6. Bidang Penetapan tanah ulayat 
7. Bidang pemanfaatan dan penyelesaian masalah tanah kosong

8. Bidang ijin membuka tanah

9. Bidang perencanaan penggunaan tanah

Pasal 17 Peraturan Pemerintah 41 Tahun 2007 tentang Organisasi Perangkat Daerah, menentukan bahwa kecamatan merupakan wilayah kerja camat sebagai perangkat daerah kabupaten dan daerah kota.

Adapun bentuk pelimpahan kewenangan pemerintahan untuk menangani sebagian urusan otonomi daerah meliputi aspek :
a. Perizinan
b. Rekomendasi
c. Koordinasi
d. Pembinaan
e. Pengawasan
f. Fasilitasi
g. Penetapan
h. Penyelenggaraan; dan
i. Kewenangan lain yang dilimpahkan

Camat sebagai perangkat daerah, disamping mempunyai tugas melaksanakan kewenangan pemerintahan yang dilimpahkan oleh bupati/walikota untuk menangani sebagian urusan otonomi daerah berdasarkan peraturan bupati/ walikota, camat juga menyelenggarakan tugas umum pemerintahan.

Pelimpahan kewenangan pemerintahan dari walikota kepada camat di Kota Bandar Lampung tertuang pada Peraturan walikota Bandar lampung nomor 87 tahun 2008. Khusus pelimpahan dibidang pertanahan diatur pada Pasal Pasal 5 ayat (1) huruf E

\subsection{Peran Kecamatan Sebagai \\ Perangkat Daerah Dalam \\ Pelayanan Pertanahan Karena \\ Tugas Umum Pemerintahan}

Sebelum lahirnya UU Nomor 32 tahun 2004 dan PP Nomor 38 tahun 2007 serta Perwali Kota Bandar Lampung Nomor 87 tahun 2008, Berdasarkan peraturan perundangan tertentu Camat dan Lurah diberi kewenangan melaksanakan pelayanan pertanahan antara lain :

\subsubsection{Pelayanan pertanahan berupa menguatkan Surat Keterangan Tanah}

Dasar hukum Asisten Wedana dapat menguatkan Surat Keterangan Tanah adalah Pasal 18 ayat (1) PP. No. 10 tahun 1961 tentang Pendaftaran Tanah yang menentukan bahwa : Atas permohonan yang berhak, maka sesuatu hak atas tanah secara lengkap dapat pula dibukukan dalam daftar buku tanah di desa desa yang pendaftaran tanahnya belum diselenggarakan.

Untuk membukukan hak tersebut kepala pendaftaran tanah harus sampaikan surat atau surat surat bukti hak dan keterangan kepala desa yang dikuatkan oleh Asisten Wedana yang memberikan surat atau surat surat bukti hak itu.

$$
\text { Asisten Wedana yang }
$$

dimaksud dalam ketentuan tersebut diatas, sudah tidak digunakan lagi, dirubah dengan nama Camat sebagai Kepala Wilayah. Kemudian berdasarkan UU No. 32 tahun 2004 tentang Pemerintahan Daerah dan dikuatkan dengan PP Nomor 41 tahun 2007 tentang Susunan Organisasi dan Tata Kerja Perangkat Daerah, ditentukan bahwa Camat adalah kepala kecamatan yang 
merupakan Perangkat daerah dari kabupaten/kota.

Berdasarkan Pasal 14 ayat (1) huruf K UU No. 32 tahun 2004 menentukan bahwa kabupaten/kota mempunyai kewenangan dalam bidang pelayanan pertanahan. Hal ini berarti kecamatan sebagai perangkat daerah dapat memberikan pelayanan pertanahan berdasarkan pelimpahan dari bupati/walikota.

Surat Keterangan Tanah (SKT) seperti ditentukan PP No. 10 tahun 1961 tentang Pendaftaran Tanah adalah surat keterangan yang dibuat oleh lurah berdasarkan berita acara pemeriksaan tanah dan pernyataan tua tua kampung, kemudian dikuatkan oleh camat yang berisikan keterangan tentang pembuktian hak atas tanah adat yang belum terdaftar, sehubungan tanah tersebut akan dialihkan atau akan diajukan permohonan haknya. Jadi sahnya SKT adalah sejak dikuatkan dengan ditandatangani oleh camat sebagai kepala kecamatan yang menurut PP No. 41 tahun 2007 sebagai perangkat daerah yang diangkat berdasarkan Surat Keputusan Walikota/Bupati, bukan kedudukan Camat sebagai PPAT yang diangkat berdasarkan Surat Keputusan Kepala Kantor Wilayah Badan Pertanahan Nasional Propinsi.

Jika tanah adat akan dialihkan SKT berfungsi sebagai salah satu dasar untuk membuat Akta PPAT, di samping alat bukti lainnya misalnya segel atau alat bukti hak lama lainnya. Tetapi jika akan langsung dimohonkan haknya, SKT harus diperkuat dengan Surat pernyataan penguasaan fisik bidang tanah (sporadic) dan surat pernyataan pemilikan yang dibuat oleh pemilik tanah dan dikuatkan oleh lurah letak tanah yang bersangkutan.
Akan tetapi sejak berlakunya PP No. 24 tahun 1997 tentang Pendaftaran Tanah, Pasal 18 ayat (1) PP No. 10 tahun 1961 yang menentukan kewenangan camat untuk menguatkan Surat Keterangan Tanah yang berfungsi menerangkan tentang tanah adat belum terdaftar sudah tidak diperlukan lagi. Hal ini berarti setelah adanya PP No. 24 tahun 1997 SKT yang dikuatkan oleh camat sebagai dasar untuk membuat akta PPAT dalam peralihan hak dan sebagai alat pembuktian hak lama untuk pembukuan hak tidak diwajibkan lagi.

Tetapi alat pembuktian hak lama dalam rangka pembukuan hak atas tanah adat yang belum terdaftar, menurut Pasal 24 ayat (1) dan( 2) PP Nomor 24 tahun 2007 adalah berupa surat pernyataan kepemilikan dan surat pernyataan penguasaan fisik bidang tanah (sporadic).

Surat pernyataan pemilikan dan surat pernyataan penguasaan fisik bidang tanah (sporadic) sebagai alat pembuktian hak lama dari tanah adat yang belum terdaptar, di Kecamatan Tanjungkarang Timur dibuat sendiri dan ditandatangani oleh pemilik tanah dan beberapa orang saksi dan kemudian di kuatkan oleh lurah letak tanah yang bersangkutan, tidak lagi dikuatkan oleh camat, seperti pada SKT menurut Pasal 18 ayat (1) PP No. 10 tahun 1961.

Tetapi dalam praktek walaupun Pasal 18 ayat (1) PP No. 10 tahun 1961 tidak berlaku lagi, dalam rangka memperkuat pembuktian dan pembukuan hak lama dari tanah adat yang belum terdaftar, masih dibuatkan SKT yang dikuatkan oleh Camat, walaupun sudah ada alat pembuktian hak seperti yang ditentukan dalam Pasal 24 ayat (1) dan (2) PP no 24 tahun1997 dan hal 
ini tidak dilarang atau dipermasalahkan oleh Kepala Kantor Pertanahan sebagai pelaksana pendaftaran tanah.

Menurut hasil wawancara dengan camat tanjungkarang timur, tidak dilarangnya oleh Kepala kantor Pertanahan lurah membuat SKT yang kemudian dikuatkan oleh camat, tujuannya untuk menimalisir kesalahan atau ketidak benaran data dalam rangka pembukuan hak atas tanah adat yang belum terdaftar. Karena SKT itu dikeluarkan berdasarkan pernyataan tua tua kampung yang tahu betul akan asal usul atau riwayat tanah yang bersangkutan, sehingga diharapkan dapat mengurangi kesalahan data baik data fisik maupun data yuridis yang diperlukan.

Pembuatan SKT oleh lurah yang kemudian dikuatkan oleh camat tidak memerlukan waktu lama, tetapi terkadang penyelesaian SKT menjadi agak terhambat, karena pihak pihak yang akan menandatangani berita acara pemeriksaan tanah dan pernyataan tua tua kampung sebagai dasar dibuat dan dikuatkanya SKT, seperti tua tua kampung, pamong pamong setempat yaitu Ketua lingkungan, ketua RT dan pemilik pemilik tanah yang berbatasan memerlukan waktu yang lama.

\subsubsection{Pelayanan pertanahan berupa menguatkan Surat Keterangan kewarisan dan surat pernyataan ahli waris.}

Pasal 26 ayat (1) PP Nomor 10 tahun 1961 menentukan bahwa untuk pendaftaran peralihan hak karena pewarisan mengenai tanah yang belum dibukukan, maka kepada Kantor Pendaftaran Tanah harus diserahkan : a. surat atau surat surat bukti hak yang disertai keterangan kepala desa yang membenarkan surat atau surat surat bukti hak itu, Keterangan kepala desa tersebut harus dikuatkan oleh asisten wedana.

b. Surat wasiat dan jika tak ada surat wasiat surat keterangan warisan dari instansi berwenang.

Asisten Wedana dimaksud pada PP No. 10 tahun 1961 di atas, menurut PP No. 24 tahun 1997 tentang Pendaftaran Tanah adalah Camat.ketentuan diatas berarti Dalam rangka pendaftaran peralihan hak karena pewarisan dari tanah yang belum pernah dibukukan, menurut Pasal 26 ayat (1) huruf a diatas, berarti disamping harus diserahkan surat pembuktian hak, juga harus disertai Surat Keterangan Tanah yang dibuat oleh Kepala desa yang telah dikuatkan oleh asisten wedana (camat). Sedangkan yang dimaksud surat keterangan warisan pada Pasal 26 ayat (1) huruf b, menurut Pasal 111 ayat (1) huruf C4 adalah surat keterangan ahli waris sebagai surat tanda bukti sebagai ahli waris bagi warganegara Indonesia penduduk asli, yang dibuat oleh para ahli waris dengan disaksikan oleh 2 orang saksi dan dikuatkan oleh kepala desa/kelurahan dan camat tempat tinggal pewaris pada waktu meninggal dunia.

Memperhatikan uraian diatas, walaupun PP No. 10 tahun 1961 sudah tidak berlaku lagi. Akan tetapi mengenai peran camat dalam menguatkan surat keterangan ahli waris jelas diatur yaitu Pasal 111 ayat (1) huruf C4 Peraturan Kepala BPN no. 3 tahun 1997 tentang Ketentuan pelaksanaan PP no. 24 tahun 1997 tentang Pendaftaran tanah. 
Hanya saja di Kecamatan Tanjung Karang Timur nama blanko yang tertulis bukan surat keterangan ahli waris tetapi tertulis surat keterangan kewarisan, tetapi fungsinya sama sebagai surat tanda bukti sebagai ahli waris yaitu surat yang dibuat sendiri oleh ahli waris atau para ahli waris yang berisikan keterangan tentang sudah meninggalnya pewaris yang dibuktikan dengan surat keterangan kematian dari Lurah atau rumah sakit, dan tentang identitas lengkap dari ahli waris atau para ahli waris. Kemudian surat keterangan ahli waris ditandatangi oleh ahli waris atau para ahli waris, dua orang saksi, diketahui oleh lurah kemudian dikuatkan oleh camat.

Dalam pendaftaran peralihan hak karena pewarisan atas tanah yang belum terdaftar, jika ahli warisnya hanya satu orang maka didaftar berdasarkan surat ahli waris atau surat tanda bukti sebagai ahli waris yang sudah dikuatkan oleh camat. Wajib diserahkan juga :

a. Surat bukti hak berupa bukti tertulis, keterangan saksi dan atau surat pernyataan yang bersangkutan (surat pernyataan pemilikan) seperti dikehendaki Pasal 24 ayat (1) PP No. 24 tahun 1997 atau surat keterangan kepala desa/lurah yang menerangkan bahwa yang bersangkutan menguasai bidang tanah seperti yang dikehendaki Pasal 24 ayat (2) PP. No. 24 tahun 1997.

b. Surat keterangan Kepala Kantor Pertanahan yang menerangkan bahwa tanah yang bersangkutan belum bersertifikat.

Akan tetapi jika dalam pendaftaran hak karena pewarisan atas tanah yang belum bersertifikat ahli warisnya lebih dari satu orang, maka ditentukan sebagai berikut :

Apabila akta pembagian waris memuat keterangan bahwa hak atas tanah tertentu jatuh pada penerima warisan tertentu, maka pendaftaran peralihan hak dilakukan kepada ahli waris tertentu tersebut berdasarkan surat tanda bukti sebagai ahli waris dan dan akta pembagian warisan tersebut. Wajib diserahkan juga syarat seperti yang dikehendaki Pasal 39 ayat (1 huruf $\mathrm{b}$ angka 1 dan $2 \mathrm{PP}$ no. 24 tahun 1997 tentang pendaftaran tanah.

Apabila akta pembagian warisan memuat keterangan bahwa dibagi bersama antara beberapa penerima warisan atau belum ada akta pembagian warisan, maka pendaftaran peralihan hak dilakukan pada penerima yang diberi hak sebagai hak bersama mereka berdasarkan Surat keterangan ahli waris dan atau akta pembagian bersama tersebut.

Akta pembagian waris dibuat dalam bentuk akta dibawah tangan oleh semua ahli waris dengan disaksikan oleh dua orang saksi atau dengan akta notaries. Tidak ada ketentuan tentang apakah akta dibawah tangan yang dibuat oleh para ahli waris itu harus dikuatkan oleh lurah dan atau camat. Lurah dan camat manakah yang harus menandatangani surat keterangan ahli waris dan akta pembagian waris, karena dalam praktek antara tempat tinggal ahli waris dengan tempat tanah tidak sama dikelurahan dan kecamatan yang sama.

Memperhatikan dokumen pertanahan yang ada di kantor Kecamatan Tanjungkarang Timur, tidak sama dengan seperti yang ditentukan dalam Peraturan Kepala BPN no 3 tahun 1997 yaitu surat 
keterangan ahli waris di arsip TKT tertulis Surat Keterangan Kewarisan, sedangkan Akta pembagian waris di arsip TKT tertulis surat pernyataan ahli waris. Akan tetapi isi dan tujuannya tetap sama tidak berbeda.

Berdasarkan hasil wawancara dengan Camat Tanjung Karang Timur, walaupun tidak ada ketentuan bahwa akta pembagian warisan di bawah tangan perlu di kuatkan oleh lurah dan camat, tetapi karena antara surat keterangan ahli waris yang sudah dikuatkan oleh lurah dan camat dengan akta pembagian warisan itu merupakan satu kesatuan yang tidak terpisahkan dalam rangka pendaftaran peralihan hak karena pewarisan, maka akta pembagian warisan dibawah tangan juga perlu dikuatkan oleh lurah dan camat, dengan tidak ada penambahan biaya. Hal ini menunjukan bahwa camat TKT sangat aktif dalam memberikan pelayanan pertanahan kepada masyarakat dengan cara memberikan kepastian perlindungan hukum dalam pembagian hak warisan antara para penerima warisan, melalui penandatangan akta pembagian warisan dibawah tangan.

\subsubsection{Pelayanan pertanahan berupa menguatkan Surat Keterangan Pemakaian Tanah Negara (SKPTN) dan memberikan rekomendasi permohonan hak atas tanah negara.}

Status tanah terdiri dari tanah negara dan tanah hak, terhadap tanah negara dapat diajukan menjadi tanah hak dengan cara mengajukan permohonan hak kepada Negara. Memperoleh tanah hak dengan cara mengajukan permohonan tanah Negara disebut memperoleh tanah hak dengan cara penetapan pemerintah. Demikian juga di Kecamatan Tanjung Karang Timur terdapat tanah negara yang mayoritas sudah ditempati oleh masyarakat untuk rumah tempat tinggal. Tanah negara tersebut berupa tanah bekas perkebunan PTPN dan tanah PT KAI dengan hak pengelolaan yang ada disepanjang rel kereta api, yaitu antara lain di kelurahan Tanjung Gading, Tanjung Raya, Rawa Laut, Kota Baru, Jagabaya I, Sawah Brebes, dan Sawah lama. Tanah Negara dan tanah hak pengelolaan yang tersebar dibeberapa kelurahan tersebut, oleh masyarakat pada umumnya sudah digunakan untuk tempat berdirinya rumah tinggal.

Rumah tinggal merupakan kebutuhan dasar manusia selain pangan dan sandang oleh karena itu pemerintah dalam rangka menjamin kelangsungan pemilikan rumah tinggal bagi warganegara Indonesia, perlu memberikan jaminan atas kelangsungan hak atas tanah tempat rumah tinggal itu berdiri.

Oleh karena itu pemerintah telah mengeluarkan kebijakan tentang pemberian hak milik atas tanah untuk rumah tinggal. Jika pemberian hak milik secara umum berdasarkan Keputusan Menteri Negara Agraria /Kepala BPN nomor 6 tahun 1998 tentang Pemberian Hak Milik Untuk Rumah Tinggal. Tetapi bagi tanah Negara dengan pemberian hak milik secara individual berdasarkan PMDN Nomor 6 tahun 1972 yang telah dirubah dengan Peraturan Menteri Negara Agraria nomor 3 tahun 1999 tentang Pelimpahan Kewenangan dan Pembatalan Keputusan pemberian Hak atas tanah Negara, dan berdasarkan PMDN Nomor 5 tahun 1973 yang sudah dirubah dengan Peraturan Menteri Negara Agraria 
Nomor 9 tahun 1999 tentang Tata Cara Pemberian dan Pembatalan Hak atas tanah Negara dan Hak Pengelolaan.

Di kecamatan Tanjungkaranag Timur pemakaian tanah Negara mayoritas dipakai untuk Rumah tinggal yang diajukan secara individual oleh pemegang hak, jadi pemberian hak miliknya secara individual dengan satu penetapan pemberian hak.

Untuk mengajukan permohonan hak milik atas tanah negara menurut ketentuan tersebut diatas disyaratkan disamping memuat keterangan mengenai pemohon hak (data yuridis), keterangan mengenai tanahnya (data fisik), di syaratkan juga ada keterangan lain yang dianggap perlu. Keterangan lain yang dianggap perlu tersebut antara lain adanya rekomendasi permohonan hak atas atas Negara yang dibuat oleh Lurah dan dikuatkan oleh Camat. Lurah mengeluarkan rekomendasi tersebut berdasarkan Surat Keterangan Pemakaian Tanah Negara (SKPTN) dan SKPTN dikeluarkan berdasarkan berita acara pemeriksaan tanah dan pernyataan tua tua kampung. Adanya peran lurah dan camat dalam permohonan hak atas Negara melalui rekomendasi diharapkan ada kepastian akan kebenaran data dan pemakaian tanah, karena lurah dan camat dalam mengeluarkan rekomendasi berdasarkan keterangan berbagai pihak yaitu pemilik tanah yang mengajukan permohonan, tua tua kampung, saksi saksi, ketua lingkungan dan ketua RT serta pemilik tanah yang berbatasan dengan tanah yang dimohonkan.

\subsection{Peran Kecamatan Sebagai Perangkat Daerah Dalam}

\section{Pelayanan Pertanahan Karena Pelimpahan Kewenangan Dari Walikota.}

Peraturan Walikota nomor 87 tahun 2008 merupakan perintah dari Pasal 17 ayat (4) PP. Nomor 41 tahun 2007 tentang Organisasi Perangkat Daerah yang menentukan bahwa pelimpahan sebagian kewenangan pemerintahan dari bupati/walikota kepada camat untuk menangani urusan otonomi daerah ditetapkan dengan peraturan bupati/walikota.

Salah satu urusan otonomi daerah yang dilimpahkan oleh Walikota Bandar Lampung berdasarkan Peraturan Walikota Nomor 87 tahun 2008 adalah urusan pertanahan. Urusan pertanahan yang menjadi kewenangan pemerintah kabupaten/kota terdapat dilampiran Peraturan Pemerintah Nomor 37 tahun 2008, ada 9 (Sembilan) bidang, tetapi yang dilimpahkan Walikota Bandar lampung kepada Camat di Kota Bandar lampug seperti ditentukan dalam Pasal 5 ayat (1) huruf E Peraturan Walikota Nomor 87 tahun 2008 adalah :

1. Pengawasan atas tanah Negara dan tanah asset Pemerintah Daerah di wilayah kerjanya

2. Pembantuan terhadap pelaksanaan pembebasan dan pelepasan tanah hak milik yang akan dipergunakan untuk kepentingan umum, serta perubahan status tanah dari tanah Negara menjadi tanah hak milik sesuai dengan ketentuan peraturan perundangu undangan.

3. Pelaksanaan monitoring dan invertarisasi terhadap setiap kegiatan yang berkaitan dengan penggunaan tanah terlantar, tanah 
Negara bebas dan tanah timbul diwilayah kerjanya.

Sedangkan kewenangan Pemda kabupaten/kota dibidang pertanahan ditentukan secara rinci dalam lampiran PP Nomor 38 tahun 2007 tentang Pembagian Urusan Pemerintahan Antara Pemerintah, Pemerintah Daerah Propinsi dan Pemerintah Daerah Kabupaten/Kota, sebagai berikut :

\subsubsection{Penerbitan surat keputusan izin lokasi}

Izin lokasi adalah izin yang diberikan kepada perusahaan untuk memperoleh tanah yang diperlukan dalam rangka penanaman modal yang berlaku pula sebagai izin pemindahan hak dan untuk menggunakan tanah tersebut guna keperluan usaha penanaman modalnya. Kewenangan ini diatur dalam Peraturan Kepala BPN nomor 2 tahun 1999 tentang izin lokasi dan dipertegas di dalam PP No.38 tahun 2007.

Menurut Keterangan Camat Tanjungkarang Timur dalam rangka penerbitan surat keputusan izin lokasi, tidak termasuk kegiatan urusan pertanahan yang dilimpahkan walikota kepada kecamatan. Oleh karena itu tidak dimasukan kedalam Peraturan Walikota nomor 87 tahun 2008, Camat dan lurah dari wilayah tempat tanah yang dimohonkan izin lokasi, hanya diundang sebagai salah satu peserta undangan pada waktu pelaksanaan rapat koordinasi antar instansi yang dipimpin oleh walikota atau pejabat yang ditunjuk secara tetap olehnya Camat dan lurah dapat memberikan masukan atau pendapat dalam rangka penerbitan surat keputusan izin lokasi. Tidak ada keterlibatan Camat dalam bentuk surat keterangan tertulis, sehingga tidak ada tanggungjawab hukum Camat dalam penerbitan surat keputusan izin lokasi. Berakaitan dengan perizinan dalam rangka menserasikan dan mensinergikan penataan ruang di Kota Bandar Lampung serta sesuai dengan Peraturan Menteri Dalam Negeri Nomor 50 tahun 2009 tentang Pedoman Koordinasi Penataan Ruang Daerah, maka Pemerintah Kota Bandar Lampung mengeluarkan Keputusan Walikota Bandar Lampung Nomor 50/23/HK/2010 tanggal 2 Maret 2010 tentang Badan Koordinasi Penataan Ruang Daerah Kota Bandar Lampung. Ada jenis perizinan dengan klasifikasi tertentu yang perlu mendapatkan rekomendasi dari Badan Koordinasi Penataan Ruang (BKPRD),

\subsubsection{Pengadaan Tanah Bagi Pelaksanaan Pembangunan Untuk Kepentingan Umum.}

Kewenangan Pemda ini diatur dalam Perpres 36 tahun 2005 yang telah diganti dengan Perpres no. 65 tahun 2006 tentang Pengadaan Tanah Bagi Pelaksanaan Pembangunan Untuk Kepentingan Umum, dipertegas kembali dalam PP no. 38 tahun 2007. Camat dan lurah yang wilayah kerjanya menjadi tempat pengadaan tanah untuk kepentingan umum, maka ditunjuk sebagai salah satu anggota panitia pengadaan tanah kota yang dibentuk oleh Walikota. Hal ini sudah ditentukan Pasal 6 ayat (5) Perpres 36 tahun 2005 yang sudah digantikan dengan Perpres 65 tahun 2006, bahwa susunan keanggotaan pantia pengadaan tanah terdiri atas unsur perangkat daerah terkait. Oleh karena itu kewenangan walikota ini termasuk yang 
dilimpahkan ke Camat yang dipertegas melalui Perwali Kota Bandar lampung nomor 87 tahun 2008.

Di samping itu juga berdasarkan Peraturan Walikota Bandar Lampung Nomor 87 tahun 2008, Walikota Bandar lampung melimpahkan kepada Camat untuk membantu pelaksanaan perubahan status tanah Negara menjadi tanah hak milik. Mengenai peran camat dan lurah dalam perubahan status tanah Negara menjadi tanah hak milik adalah dalam bentuk menerbitkan Rekomendasi Permohonan Hak Atas Tanah Negara berdasarkan SKPTN dan Berita acara pemeriksaan tanah dan pernyataan tua tua kampung. Kewenangan ini memang sudah ditentukan didalam Keputusan Menteri Negara Agraria Nomor 6 tahun 1998, Peraturan Menteri Negara Agraria/Kepala BPN Nomor 3 dan Nomor 9 tahun 1999.

Di Kecamatan Tanjung Karang Timur pelayanan pertanahan berupa permohonan

Penerbitan

Rekomendasi Permohonan Hak atas Tanah Negara yang diajukan oleh masyarakat adalah permohonan hak milik atas tanah negara untuk rumah tinggal, berdasarkan Peraturan Menteri Negara Agraria Nomor 6 tahun 1998 tentang Pemberian hak Milik Atas Tanah Untuk Rumah Tinggal.

\subsubsection{Penyelesaian sengketa tanah garapan.}

Penyelesaian sengketa tanah garapan yang menjadi kewenangan Pemerintah Kabupaten/Kota berdasarkan PP No. 38 tahun 2007 adalah :

a. Penerimaan dan pengkajian laporan pengaduan sengketa tanah garapan b. Penelitian terhadap obyek dan subyek sengketa

c. Pencegahan meluasnya dampak sengketa tanah garapan

d. Konsultasi dengan kantor pertanahan untuk menetapkan langkah penanganannya

e. Fasilitasi musyawarah antar pihak yang bersengketa untuk mendapatkan kesepakatan para pihak.

Kewenangan tersebut diatas, tidak dilimpahkan Walikota Kota Bandar Lampung kepada Camat melalui Peraturan Walikota Nomor 87 tahun 2008, karena di Kota Bandar Lampung hampir tidak ada kasus sengketa tanah garapan.

\subsubsection{Penyelesaian Masalah Ganti Kerugian dan Santunan Tanah Untuk Pembangunan}

Dalam penyelesaian masalah ganti kerugian dan santuan tanah untuk pembangunan yang menjadi kewenangan Pemerintah Daerah Kabupaten/Kota menurut PP. 38 tahun 2007 adalah:

a. Pembentukan Tim pengawasan pengendalian

b. Penyelesaian masalah ganti kerugian dan santunan tanah untuk pembangunan.

Kewenangan dalam masalah penyelesaian ganti kerugian dan santunan tanah untuk pembangunan, sebenarnya merupakan salah satu bagian dari tugas kepanitian pengadaan tanah untuk kepentingan umum. Oleh karena itu walaupun tidak tersurat dalam Perwali nomor 
87 tahun 2008, tetapi camat dan lurah sebagai salah satu panitia pengadaan tanah untuk kepentingan umum yang paling dekat dan mengerti kondisi masyarakatnya perlu untuk dilibatkan dalam penyelesaian masalah ganti kerugian dan santunan tanah untuk pembangunan sebagai salah satu tim pengawas pengendalian.

\subsubsection{Penetapan subyek dan obyek redistribusi tanah serta ganti kerugian tanah kelebihan maksimum dan tanah absentee}

a. Pembentukan panitia pertimbangan landreform

b. Pelaksanaan sidang yang membahas hasil inventarisasi untuk penetapan subyek dan obyek redistribusi tanah serta ganti kerugian tanah kelebihan maksimum dan tanah absentee.

c. Pembuatan hasil sidang dalam berita acara

d. Penetapan tanah kelebihan maksimum dan absentee sebagai obyek landreform berdasarkan hasil sidang panitia

e. Penetapan para penerima redistribusi tanah kelebihan maksimum dan tanah absentee berdasarkan hasil sidang panitia Penerbitan surat keputusan subyek dan obyek redistribusi tanah serta ganti kerugian.

Kewenangan tersebut diatas, merupakan pelaksanaan dari salah satu program landreform, yaitu program redistribusi tanah obyek landreform. Pengaturan Landreform di Indonesia dilaksanakan berdasarkan Undang Undang nomor 56/Prp/tahun 1960 tentang Penetapan Luas Tanah Pertanian yang merupakan pelaksanaan dari
Pasal 7. 10 dan 17 UU nomor 5 tahun 1960 tentang Peraturan Dasar Pokok Pokok Agraria.Sebagai peraturan pelaksananya dikeluarkan PP. Nomor 224 tahun 1961 yang telah ditambah dan diubah dengan PP Nomor 41 tahun 1964 tentang Pelaksanaan Pembagian Tanah dan Pemberian Ganti Kerugian. Dalam pelaksanaan program landreform dibentuk panitia pertimbangan Landreform tinngkat pusat, propinsi dan kabupaten/kota. Tetapi dalam pelaksanaan tugas Landreform dilakukan juga oleh Gubernur/Bupati/Walikota/Camat/Ke pala Desa.

Camat dan Kepala Desa bertugas membantu bupati/walikota kepala daerah dalam kegiatan yang berhubungan dengan program landreform, walaupun didalam Perwali Kota Bandar Lampung nomor 87 tahun 2008 tidak ada ditentukan pelimpahan kewenangan dalam pelaksanaan program landreform karena di Kota Bandar lampung tidak ada tanah obyek landreform yang akan diredistribukan kepada masyarakat.

\subsubsection{Penetapan Tanah Ulayat}

Kewenangan kabupaten/kota dalam rangka penetapan tanah ulayat adalah :

a. Pembentukan panitia peneliti

b. Penelitian dan kompilasi hasil penelitian

c. Pelaksanaan dengar pendapat umum dalam rangka penetapan tanah ulayat

d. Pengusulan rancangan Perda tentang penetapan tanah ulayat

e. Mengusulkan pemetaan dan pencatatan tanah ulayat dalam 
daftar tanah kepada kantor pertanahan kabupaten/kota

f. Penanganan masalah tanah ulayat melalui musyawarah dan mufakat.

\section{Pasal 3 UUPA menentukan} bahwa hak ulayat atas tanah masyarakat hukum adat diakui keberadaannya sepanjang kenyataannya masih ada. Untuk mengetahui tentang keberadaan hak ulayat tersebut maka tentunya diperlukan pengkajian melalui penelitian dan penetapan hak ulayat.

$$
\text { Kewenangan Pemerintah }
$$

Daerah dalam penelitian dan penentuan tanah ulayat sudah diatur dalam Peraturan Menteri Negara Agraria/Kepala BPN Nomor 5 tahun 1999 tentang Pedoman Penyelesaian Masalah Hak Ulayat Masyarakat Hukum Adat. Pasal 5 ayat (1) peraturan tersebut menentukan bahwa penelitian dan penentuan masih adanya hak ulayat dilakukan oleh Pemerintah Daerah.dengan mengikut sertakan pakar pakar hukum adat, masyarakat hukum adat yang ada didaerah yang bersangkutan, LSM dan instansi instansi yang mengelola sumber daya alam.

Di Kota Bandar Lampung keberadan tanah ulayat tidak ada lagi, oleh karena itu kegiatan penelitian dan penetapan hak ulayat tidak diperlukan dan tidak dilimpahkan secara tersurat dalam Perwali 87 tahun 2008.

\subsubsection{Pemanfaatan Penyelesaian Tanah Kosong.}

dan Masalah

Mengenai

ketentuan

pemanfaatan tanah kosong untuk tanaman pangan diatur dalam Peraturan Menteri Negara Agraria Nomor 3 tahun 1998 tentang Pemanfaatan Tanah Kosong Untuk Tanaman Pangan. Kewenangan Pemda kabupaten/kota sebagai berikut :

a. Inventarisasi dan identifikasi tanah kosong untuk pemanfaatan tanaman pangan semusim.

b. Penetapan bidang bidang tanah sebagai tanah kosong yang dapat digunakan untuk tanaman pangan semusim bersama dengan pihak lain berdasarkan perjanjian

c. Penetapan pihak pihak yang memerlukan tanah untuk tanaman pangan semusim dengan mengutamakan masyarakat setempat

d. Fasilitasi perjnjian kerjasama antara pemegang hak atas tanah dengan pihak yang akan memanfaatkan tanah dihadapan/diketahui oleh kepala desa/lurah dan camat setempat dengan perjanjian untuk dua kali musim tanam

e. Penanganan masalah yang timbul dalam pemanfaatan tanah kosong jika salah satu pihak tidak memenuhi kewajiban dalam perjanjian.

Mengenai kewenangan Pemda Kota Bandar Lampung dalam pemanfataan dan penyelesaian tanah kosong, dengan tegas Walikota melimpahkan kepada Camat untuk melaksanakan monitoring dan inventarisasi, termasuk monitoring dan inventarisasi penggunaan tanah terlantar, tanah Negara bebas dan tanah timbul yang ada di kecamatan, seperti ditentukan dalam Pasal 5 ayat (1) huruf e angka 3 Perwali Kota Bandar Lampung Nomor 87 tahun 2008. 


\subsubsection{Kewenangan Pemerintah Daerah Dalam Pemberian Izin Membuka Tanah.}

Berkaitan dengan izin

membuka tanah Pemda

kabupaten/kota berwenang untuk :

a. Penerimaan dan pemeriksaan permohonan

b. Pemeriksaan lapang dengan memperhatikan kemampuan tanah, status tanah dan rencana umum tata ruang wilayah (RTRW) kabupaten/kota

c. Penerbitan izin membuka tanah dengan memperhatikan pertimbangan teknis dari kantor pertanahan kabupaten/kota'

d. Pengawasan dan pengendalian penggunaan izin membuka tanah.

Pada waktu masih berlakunya PMDN Nomor 6 tahun 1972 tentang Pelimpahan Kewenangan Pemberian Hak Atas Tanah, Pasal 11 menentukan bahwa kecamatan mempunyai kewenangan memberikan izin membuka tanah yang luasnya tidak lebih dari $2 \mathrm{Ha}$, akan tetapi dengan tidak berlakunya lagi peraturan tersebut, kecamatan tidak diperkenankan lagi mengeluarkan izin membuka tanah. Oleh karena itu bupati/walikota dilarang melimpahkan kewenangan memberikan izin membuka tanah kepada kecamatan. Perwali Kota Bandar Lampung Nomor 87 tahun 2008 tidak memberikan pelimpahan dalam pemberian izin pembukaan tanah, karena Camat dilarang untuk memberikan izin membuka tanah.

PMDN nomor 6 tahun 1972 telah digantikan dengan Peraturan Menteri Negara Agraria Nomor 3 tahun 1999 tentang Pelimpahan Kewenangan dan Pembatalan Keputusan Pemberian Hak Atas
Tanah Negara, didalamnya tidak ada pengaturan tentang pemberian izin membuka tanah.

\subsubsection{Perencanaan Penggunaan Tanah Wilayah Kabupaten/Kota.}

Kewajiban melaksanakan Perencanaan pengunanaan tanah merupakan perintah dari Pasal 14 Undang Undang Nomor 5 tahun 1960 tentang Peraturan Dasar Pokok Pokok Agraria.

Pemerintah Daerah

Kabupaten/Kota berwenang dalam Perencanaan penggunaan tanah, yang merupakan sub sistem dari penatagunaan tanah seperti ditentukan dalam Peraturan Pemerintah Nomor 16 tahun 2004 tentang Penatagunaan Tanah.

Sedangkan Penatagunaan tanah merupakan sub sistem dari penataan ruang yang di atur dengan Undang Undang Nomor 26 tahun 2007 tentang Penataan Ruang.

Dalam rangka perencanaan penggunaan tanah kabupaten/kota melaksanakan :

a. Pembentukan Tim Koordinasi Tingkat kabupaten/Kota

b. Kompilasi data dan informasi yang terdiri dari 1). Peta pola penggunaan tanah atau peta wilayah tanah usaha Atau peta persediaan tanah dari kantor pertanahan Setempat 2). Recana Tata Ruang Wilayah 3). Rencana pembagunan yang akan menggunakan tanah, baik Rencana pemerintah, pemerintah kabupaten/kota maupun Investasi staswa.

c. Analisis kelayakan letak lokasi sesuai dengan ketentuan dan kreteria teknis dari instansi terkait 
d. Penyiapan draft rencana letak kegiatan penggunaan tanah

e. Pelaksanaan rapat koordinasi terhadap draft rencana letak kegiatan penggunaan tanah dengan instansi terkait

f. Konsultasi public untuk memperoleh masukan terhadap draft rencana letak kegiatan penggunaan tanah

g. Penyusunan draft final rencana letak kegiatan penggunaan tanah

h. Penetapan rencana letak kegiatan penggunaan tanah dalam bentuk peta dan penjelasannya dengan keputusan bupati/walikota

i. Sosialisasi tentang rencana letak kegiatan penggunaan tanah kepada instansi terkait

j. Evaluasi dan penyesuaian rencana letak kegiatan penggunaan tanah berdasarkan perubahan RTRW dan perkembangan realisasi pengembangan.

Memperhatikan ke 9 kewenangan Pemerintah Daerah kabupaten/kota seperti ditentukan dalam PP Nomor 38 tahun 2007 dan pelimpahan kewenangan pemerintahan dalam urusan pertanahan dari Walikota Kota Bandar Lampung kepada Camat berdasarkan Peraturan Walikota Nomor 87 tahun 2008, menunjukan bahwa walaupun sudah ada pensmbahan kewenangan Kepada Pemda Kota Bandar Lampung, tetapi tidak ada penambahan peran pelayanan pertanahan yang strategis kepada kecamatan. Kecamatan hanya mendapat pelimpahan dalam urusan pengawasan, monitoring dan inventarisasi terhadap tanah Negara, asset Pemda, tanah terlantar dan tanah timbul tetapi belum ada juklak dan juknisnya . Sebekum ada Perwali Kota Bandar Lampung selama ini camat memberikan pelayanan pertanahan berdasarkan tugas umum pemerintahan dan sebagai pejabat pemerintah karena jabatannya ditunjuk sebagai PPAT Sementara berdasarkan peraturan perundang undangan.

\subsection{Faktor Penghambat Peran Kecamatan Sebagai Perangkat Daerah Dalam Pelayanan Pertanahan Di Kecamatan Tanjungkarang Timur}

\subsubsection{Tanah milik adat beberapa kali beralih tanpa alat bukti kepemilikan.}

Terhadap tanah adat yang belum terdaftar, sejak tahun 1960 sudah beberapa kali beralih tidak ada bukti tertulis, maka jika akan diajukan permohonan haknya atau akan dialihkan kepada pihak lain, peran camat dan lurah yang akan menguatkan kebenaran kepemilikan tanah dengan cara menandatangani surat pernyataan kepemilikan, surat pernyataan penguasaan fisik bidang tanah sporadic, berita acara pemeriksaan tanah dan Surat Keterangan Tanah, memerlukan waktu yang lama dalam menelusuri kebenaran setiap peralihan hak tersebut. Sehingga masyarakat ada yang berpendapat jangka waktu lama dan syarat syarat permohonan pelayanan pertanahan dipersulit, pada hal camat dan lurah berusaha mencari kebenaran data kepemilikan tanah, baik data fisik maupun data yuridis adalah merupakan bentuk wujud tanggungjawab kepada masyarakat dan Negara agar surat surat yang akan dibuat dan dikuatkannya benar menurut hukum yang berlaku sehingga tidak akan menimbulkan persengketaan kepemilikan tanah di kemudian hari. 


\subsubsection{Kurang memahami tentang BPHTB dan PPH}

Camat di samping berkedudukan sebagai perangkat daerah juga mempunyai kedudukan sebagai pejabat pemerintah dalam pelayanan pertanahan yaitu sebagai Pejabat Pembuat Akta Tanah Sementara. Sehubungan dalam pembuatan akta tanah PPAT camat wajib menolak jika kepadanya tidak diserahkan Fotocofi surat tanda setoran pajak penghasilan atau fotocofi surat setoran Bea Perolehan Hak Atas tanah dan Bangunan. Masyarakat menganggap BPHTB dan PPH yang harus dibayar sebelum dibuatkan Akta merupakan satu kesatuan dengan biaya pembuatan akta. Sehingga menilai biaya membuat akta terlalu mahal.

Jika syarat ini tidak dapat dipenuhi oleh pemohon maka tidak jarang pemohon membatalkan membuat akta pada hal surat surat bukti kepemilikan yang diperlukan dalam rangka pembuatan akta yang sudah lengkap di persiapkan dan sudah dikuatkan oleh lurah dan camat, dengan sudah mengeluarkan tenaga dan waktu bahkan tidak jarang camat sudah membeli akta yang diperlukan ternyata akhirnya batal karena pemohon tidak mau membayar BPHTB seperti yang sudah ditentukan dalam Undang Undang Nomor 20 tahun 2000 dan ditindak lanjuti dengan Perda karena BPHTB sudah menjadi kewenangan daerah.

\subsubsection{Menggunakan jasa pihak ketiga yang tidak bertanggung jawab}

Tidak jarang masyarakat pemohon yang memerlukan pelayanan pertanahan dari camat dan lurah menggunakan jasa pihak ketiga, sehingga dalam rangka mengumpulkan dan melengkapi bukti kepemilikan tanah menjadi tertunda tunda dan memerlukan waktu penyelesaian yang lama dan tentunya biaya lebih besar daripada mengurus sendiri, karena tidak jarang pihak ketiga yang mengurusnya tidak bertanggungjawab atau kurang aktif untuk memenuhi persyaratan yang diperlukan dan sulit untuk dihubungi ketika sudah menerima uang dari pemohon. Hal ini menghambat peran camat dan lurah dalam memberikan pelayanan yang optimal murah cepat dan tepat.

\subsubsection{Pelimpahan \\ Urusan Pertanahan Tanpa Petunjuk}

Salah satu peran camat sebagai perangkat daerah adalah melaksanakan urusan pertanahan yang dilimpahkan oleh walikota berdasarka Perwali Kota Bandar Lampung nomor 87 tahun 2008. Pelimpahan tersebut terbatas dalam bentuk pengawasan, monitoring dan inventarisasi terhadap tanah Negara dan tanah asset Pemda, penggunaan tanah terlantar, tanah Negara bebas dan tanah timbul yang ada diwilayah kerjanya.

Akan tetapi untuk melaksanakan peran tersebut belum ada petunjuk yang pasti dan jelas jika akan melaksanakan tugas pengawasan, monitoring dan inventarisasi, sehingga camat dan lurah di Tanjungkarang Timur belum melaksanakannya, disamping itu juga di Kecamatan Tanjungkarang Timur tidak ada hubungan hukum 
masyarakat yang berkaitan dengan pengunaan tanah terlantar.

\section{PENUTUP}

\subsection{Simpulan}

Camat dalam melaksanakan urusan pelayanan pertanahan mempunyai 2 (dua) jabatan. Pertama sebagai pejabat pemerintah yang ditunjuk karena jabatannya sebagai PPAT yang diangkat berdasarkan Surat Keputusan Kepala Kantor Wilayah Badan Pertanahan Nasional Propinsi. Kedua, Camat sebagai perangkat daerah diangkat berdasarkan Surat Keputusan Kepala Daerah Kabupaten/Kota. Sebagai perangkat daerah dalam melaksanakan urusan pertanahanan, berdasarkan pelimpahan wewenang dari walikota melalui peraturan walikota dan berdasarkan peraturan perundang undangan dalam melaksanakan tugas umum pemerintahan.

\subsection{Saran}

1. Perlu di adakan penyuluhan hokum dan pelatihan untuk kepastian data fisik dan data yuridis tanah.

2. Di harapkan agar masyarakat mempunyai bukti kepemilikan tanah tidak sebatas akta dibawah tangan, tetapi dapat sampai dengan membuat Akta PPAT, diharapkan bukti setoran BPHTB dan PPH bukan disyaratkan untuk membuat Akta PPAT, tetapi merupakan syarat untuk melakukan permohonan pendaftaran hak atas tanah di Kantor Pertanahan.

3. Diadakan kebijakan yang melarang dilakukan oleh perantara, karena akan memperpanjang proses penyelesaian dan memperbesar biaya.

4. Dilakukan kelengkapan petunjuk pelaksana dan petunjuk tekhnis, agar ada keseragaman pedoman untuk seluruh kecamatan di Kota Bandar Lampung.

\section{DAFTAR PUSTAKA}

Departemen Pendidikan Nasional, 2001, Kamus Besar Bahasa Indonesia, Balai Pustaka : Jakarta.

Djohan, Djohermansyah, 1998, Reformasi Otonomi Daerah, Fakultas Hukum Universitas Surabaya : Surabaya

Murhaini, Supriansyah, 2009, Kewenangan Pemerintah Daerah Mengurus Bidang Pertanahan, LaksBang Justitia: Surabaya

Mansyur, Cholil, 1981, Penyelenggaraan

Pemerintahan di Daerah, Usaha Nasional : Surabaya

Marbun, S.F, 1997, Peradilan Administrasi Negara dan Upaya Administratif di Indonesia, Liberty: Yogyakarta Murhaini Suriansyah, 2009, kewenangan Pemerintah daerah mengurus Bidang Pertanahan, Laksbang Justitia: Surabaya

Stroink, F.A.M, Memahami Beberapa Bab Hukum Administrasi, LaksBang PressSindo : Yogyakarta

Sunarno, Siswanto, 2005, Hukum Pemerintahan Daerah di Indonesia,Sinar Grafika : Jakarta

Undang-Undang Dasar 1945

Undang-undang No. 5 Tahun 1960 tentang Peraturan Dasar Pokok-Pokok Agraria 
Peraturan Pemerintah No. 38 Tahun 2007 tentang Pembagian Urusan Pemerintahan Antara Pemerintah, Pemerintah Daerah Propinsi dan Pemerintah Daerah Kabupaten/Kota

Peraturan Pemerintah No. 41 Tahun 2007 tentang Susunan Organisasi dan Tata Kerja Perangkat Daerah

Peraturan Pemerintah No. 19 Tahun 2008 tentang Kecamatan

Peraturan Daerah Kota Bandar Lampung No. 5 Tahun 2008 tentang Organisasi Dan Tata Kerja Kecamatan dan Kelurahan Kota Bandar Lampung

Peraturan Walikota Bandar Lampung No. 31 Tahun 2008 tentang Tugas, Fungsi dan Tata Kerja Kecamatan Kota Bandar Lampung

Peraturan Walikota Bandar Lampung No. 87 tahun 2008 tentang Pelimpahahan Sebagian Kewenangan Pemerintahan dari Walikota kepada Camat. 